PART 2

Hell in Early and Medieval Islam 
Christopher Melchert - 9789004301368 Downloaded from Brill.com $\odot 4 / 26 / 2023$ 10:33:23AM via free access 


\title{
Locating Hell in Early Renunciant Literature
}

\author{
Christopher Melchert
}

Yūnus b. 'Ubayd (d. 139/756-7) is said to have thus described al-Hasan al-Bașrī (d. 110/728):

When he came, it was as if he had just buried one of his parents. When he sat, it was as if he had been a prisoner condemned to having his head struck off. When the Fire was mentioned before him, it was as if it had not been created for anyone but him. ${ }^{1}$

Unsurprisingly, the renunciants $(z u h h \bar{a} d)$ of the first three Islamic centuries often contemplated hell. For example, the Damascene Sa'īd b. 'Abd al-'Azìz (d.168/784-5?) always wept at the ritual prayer, explaining that hell was always prepresented to him. ${ }^{2}$ They looked for reminders of hell in the world. For example, it is said that the Yemeni Tāwūs (d. 106/724-5?) would sometimes walk through the market on his way to the mosque. If he saw heads roasting there, he could not sleep that night. ${ }^{3}$ Nevertheless, the literature of their sayings apparently mentions the contemplation of death more often than of hell, and elaborations on Quranic descriptions of hell are a little more common in Quranic commentaries and collections of prophetic hadith. The theme evidently illustrates how much renunciant concerns pervaded all of Islamic religious culture in the early centuries, but it also shows the renunciants more cautious about descriptions of hell than some others.

\section{Sources}

Our most voluminous sources for early piety are Abū Nu'aym (d. 430/1038), Hilyat al-awliyā', Aḥmad b. Hanbal (d. 241/855), al-Zuhd, Ibn al-Mubārak

1 Al-Jāḥiz, Bayān iii, 171. Something similar is attributed to 'Amr b. 'Ubayd apud Ahmad, Jāmici, $65^{-6 .}$

2 Abū Nu'aym, Hilya viii, 274.

3 Aḥmad, Zuhd 375449.

(C) Christopher Melchert, 2016 | DOI 10.1163/9789004301368_006

This is an open access chapter distributed under the terms of the Creative Commons Attribution-

Noncommercial 3.o Unported (CC-BY-NC 3.0) License.

Christopher Melchert - 9789004301368 
(d. 181/797), al-Zuhd, the zuhd and other sections of Ibn Abī Shayba (d. 235/849), al-Mușannaf, and Hannād b. al-Sarī (d. 243/857), al-Zuhd. ${ }^{4}$ These are all from eminent traditionists (hadith experts) and provide more sayings than any source in the traditions of $a d a b$ (e.g., the works of al-Jāhiz and Ibn Qutayba) and Sufism (e.g., the works of al-Sulamì and al-Khargūshī). These sources also include most of our earliest-attested quotations. (A partial exception is Ibn Abi 'l-Dunyā [d. 281/894], Sifat al-nār, a whole book in the adab tradition devoted to descriptions of hell. More on this below.) Moreover, traditionists seem to have been the most inclined to quote accounts of a piety that contradicted their own (here especially by contrast with the Sufis). Altogether, then, literature in the hadith tradition seems generally the least likely to reflect back projection from the ninth and later centuries. The first two of the sources just named are roughly arranged biographically, the rest topically, which of course makes it easier to find items in them dealing with hell.

The Zuhd of Ahmad b. Hanbal is extant in a version of about 2,400 items, about one-third of which does not actually come through Ahmad but only his son 'Abdallāh (d. 290/903), its evident compiler. Almost 750 more items may be added from quotations by Abū Nu'aym. ${ }^{5}$ The Zuhd of Ibn al-Mubārak is extant in two overlapping but fairly different recensions, of al-Husayn b. al-Hasan al-Marwazī (d. 246/860-1), who lived in Mecca, and of Nu'aym b. Ḥammād (d. 228/843?), who lived in Egypt until he was dragged to Iraq and imprisoned for defiance of the caliph at the Inquisition. The modern editor of the Zuhd presents first 1,627 items from al-Husayn b. al-Hasan, about 1,300 of them from Ibn al-Mubārak, then a further 436 items found in Nu'aym's recension but not al-Ḥusayn's.

Standard collections of hadith on all topics, such as the Six Books, include advice on renunciation; likewise some books of $a d a b$, such as Ibn Qutayba's 'Uyünal-akhbār. They will be drawn on here when they overlap with specialized collections of renunciant sayings. One book that I am inclined not to count as a specialized collection of renunciant sayings, despite its title, is Asad b. Mūsā (d. Old Cairo, 212/827), Kitāb al-Zuhd, of which the standard edition is that of Raif Georges Khoury. Actually, this text begins with a $b \bar{a} b$ al-zuhd comprising four items but then proceeds to the first of many sections on hell comprising 38 items, followed by other sections on the Last Judgement comprising 61 items.

4 Abū Nưaym, Hilya; Aḥmad b. Ḥanbal, Zuhd; Ibn al-Mubārak, Zuhd; Ibn Abī Shayba, Mușannaf; Hannād b. al-Sarī, Zuhd. For a list of over 60 early works on renunciation, including many not extant, see Haydar's introduction to Bayhaqī, Zuhd $47-56$, to be supplemented by the editor's introduction to Hannād, Zuhd, esp. 7 .

5 Details in Melchert, Aḥmad ibn Ḥanbal's book 349-53. 
Therefore, the title al-Zuhd was probably taken from this one small section of a doubtfully complete manuscript. Asad b. Mūsā had a strong reputation for orthodoxy, a mixed one for hadith transmission, and none that I have observed in the biographies for renunciation. ${ }^{6}$ The book scarcely belongs to the literature of zuhd any more than, say, Muslim's Șahịh, which likewise includes a section on zuhd. Khoury believes that our text is probably a fragment of the one ascribed to Asad by Ibn Khayr al-Ishbīlī, Kitāa al-Zuhd wa-l-ibāda wa-l-wara.7 This is conceivable, but Khoury seems to assume too readily that the books we have from this period were assembled in the form that we have them by their reputed authors with stable titles. Compare his careless references to the Kitāb al-Zuhd wa-l-raqāiq of Ibn al-Mubārak, actually comprising the overlapping but not identical assemblages of two disciples to Ibn al-Mubārak, as though they together constituted a single text directly from him. ${ }^{8}$ Asad b. Mūsā's book may legitimately be cited for ideas current in the ninth century; however, it should not be taken to document what particularly preoccupied renunciants as opposed to other hadith collectors.

Various things in the world were taken as salutary reminders of hell. Ibn Mas'ūd (d. 32/652-3?) melted some silver in the treasury, then sent a message to the people of the mosque, saying "Whoever wishes to look at $m u h l$, let him look at this." ${ }^{9}$ Harim b. Hayyān ( $f$ l. 1st/7th cent.) was governor of Basra for the caliph 'Umar. When some kinsmen appeared (presumptively looking for special favour), he lit a fire, then bade them approach him. They said, "By God, we cannot approach you, for the fire is between us and you." He said, "Yet you wish to meet me in a greater fire than this, in Jahannam." They went away. ${ }^{10}$ Similarly, Ibn Sīrin and some comrades were sitting with the Kufan

6 See Khoury, Introduction to Asad, Zuhd, esp. 21-30. To Khoury's list of biographies, add Dhahabī, Tärīkh xv (211-229 H.), 69-70, with additional references.

$7 \quad$ Khoury, Introduction 39-41.

8 Ibid., 38-9, 41.

9 Hannād, Zuhd i, 184-5, quoting Wakī` b. al-Jarrāh but not found in the extant collection of his, Zuhd. Țabarī presents another version of Ibn Mas'ūd's object lesson in his commentary ad Q 18:29; see Țabarī, Jāmic viii, 218. According to the Quran, the sky on the Day of Judgement will resemble muhl, then the condemned will drink something like it ( $\mathrm{Q}$ 18:29, $44: 45,70: 8)$. It is usually taken to mean "molten metal," but an alternative view interprets it as "blood and pus" (more on this below).

Ibn Sa'd, Biographien vii/1, 96 vii, 133; Aḥmad, Zuhd 232 284; Abū Nu'aym, Hilya ii, 120. 
Abū 'Ubayda b. Hudhayfa ( $f l$. 1st $/ 7$ th cent.) when a man came to him and said something the others did not catch. Abū 'Ubayda told the man, "I will ask you to put your finger in this fire", referring to a fire before them. The man refused. Then Abū "Ubayda told him, "You withhold from me one of your fingers, yet you ask me to put my whole body into the fire of Jahannam." Ibn Sīrin and his comrades supposed that the man had just offered Abū 'Ubayda a judgeship."

Sometimes hell was represented not merely by reminders but by fragments of itself. The Prophet said, "The fire of the sons of Adam that is used for fire is a seventieth of the fire of Jahannam."12 Some such thought was probably behind the early call for ritual ablutions after eating anything touched by fire, abandoned by the third/ninth century. ${ }^{13}$ (Admittedly, there continued to be a ban on burying Muslims with anything flammable, such as wood, which must have been symbolic of what might be consumed by fire, not something that hellfire had actually touched.) Extreme weather also comes directly from hell. The Prophet said, "The Fire complained to God that part of it was consuming another, so God allowed it to exhale twice, so that the severest heat and cold are from it."14 One could apparently tell where the hell was, if not directly see it, by looking at the ocean. Al-Hasan al-Bașrī said, "The sea is the Fire's cover

\footnotetext{
11 Ibn Abī Shayba, Mușannaf, k. al-zuhd 87, kalām Ikrima, xii, 413.

12 Hammām, Șahīfa no. 14; Mālik, Muwațța', recension of Yahyā al-Laythī, jahannam, mā jăàa fi șifat jahannam; Ibn al-Mubārak, Zuhd (Nu'aym) no. 308; 'Abd al-Razzāq, Mușannaf xi, 423; Aḥmad, Musnad ii, 244, 467, 478 xii, 280-1, xiv, 492-3, xvi, 77-8; Hannād, Zuhd i, 167; Dārimī, Sunan, al-raqā’iq, bāb fì qawl al-nabì ... nārukum hādhihi juz'; Bukhārī, Șahị̣̄, bad’ al-khalq 10, bāb șifat al-nār wa-annahā makhlūqa, no. 3265; Muslim, Șaḥịh, al-masājid 32, bāb istiḥbāb al-ibrād bi-l-zuhr, nos. 180-4, also al-janna, bāb fì shiddat harr jahannam, no. 2843; Tirmidhī, Jāmi', șifat jahannam 7, bāb mā jāa anna nārakum ... no. 2589; Ibn Māja, Sunan, al-zuhd 38, bāb șifat al-nār, no. 4318; Ibn Abi 'l-Dunyā, Șifa, 58 . Cf. the version in Ahmad, Musnad ii, $378 x i v, 492-3$, "This fire is a hundredth part of Jahannam."

13 See Katz, Body 102-23.

14 Hannād, Zuhd i, 169; Aḥmad, Musnad ii, 238, 277, 462, 503 xii, 188-90, xiii, 156, xvi, 37-8, 318; Mālik, Muwațta', al-șalāt 7, bāb al-nahy 'an al-șalāh bi-l-hājira, no. 27; Bukhārī, Jāmic, mawāqüt al-șalāt 9, bāb al-ibrād bi-l-zuhr, no. 537, also bad' al-khalq 10, bāb șifat al-nār waannahā makhlūqa, no. 326o; Muslim, Șaḥ̄ḥ, al-masājid 32, bāb istiḥbāb al-ibrād bi-l-zuhr, nos 185-7; Dārimī, Sunan, al-raqāiq, bābfìnafas al-jahannam; Tirmidhī, Jāmi', șifat jahannam 9, bāb mā jā̉a anna lil-nār nafasayn, no. 2592; Ibn Māja, Sunan, al-zuhd 38, bāb șifat al-nār, no. 4319; Ibn Abi 'l-Dunyā, Șifa, 58. The afternoon heat is also said to be part of hell in connection with delaying the afternoon prayer; e.g., Bukhārī,Jāmi', mawāqüt al-șalāt 9, bāb al-ibrād bi-l-zuhr, nos. 533-6, 10, bāb al-ibrād bi-l-zuhr fi 'l-safar, no. 539, and bad' al-khalq 10, bāb șifat al-nār wa annahā makhlūqa, nos. $3^{25} 5^{-9}$. And the heat of a fever is also identified with hell; e.g., Bukhārī, Jāmi', bad' al-khalq 10, bāb șifat al-nār wa-annahā makhlūqa, no. 3261, and al-țibb 28, bāb al-humā min fayh jahannam, nos. 5723, 5725-6.
} 
(al-bahr tabaq al-nār)."15 This is apparently the background to reports that it was weakened by water, perhaps on the way to our world. The Prophet said, "This fire of yours is a 7oth part of Jahannam. The fire was struck twice by the sea. If not for that, God would have made it of no use to anyone."16 'Abdallāh b. 'Amr (d. 63/683?), when sitting before a fire, would say if it leapt up, "By him in whose hand is my soul — it is taking refuge with God from the greatest fire."17

Heroes of piety found their routines interrupted by the recollection of hell. Ibn Mas'ūd fell down on seeing some smiths blowing the bellows and wept at the sight of a hot iron. ${ }^{18}$ (An anonymous worshipper was even said to have stopped to look at a forge, then sobbed and died on the spot.) $)^{19}$ 'Āmir b. 'Abd (al-)Qays (d. ca. 55/674-5) told a woman, "My daughter, Jahannam does not allow your father to sleep."20 Shaddād b. Aws (d. ca. 6o/679-80) on his bed was like a grain of wheat on a frying pan, saying "O God, the Fire has prevented me from sleeping"; then he would get up for ritual prayer. ${ }^{21}$ The Kufan Abu Maysara (d. 63/682-3) is said to have taken to his bed and said, "Would that my mother had never borne me." His wife said, "Abū Maysara: God has done well by you, having guided you to Islam." He said, "Yes, but God has made it clear to us that we are bound for the Fire without making clear to us that we are going out of it", alluding to Q 19:71, "There is none of you who will not go

15 Ahmad, Zuhd 28835 . Or perhaps the reference is specifically to the surrounding sea at the edge of the world. The Prophet is said to have explained, "The sea is Jahannam," then recited Q 18:29, which mentions surrounding although not the sea: Ibn Abi 'l-Dunyā, Șifa, 70-1.

16 Aḥmad, Musnad ii, 244 xii, 280-7; similarly, Ibn Māja, Sunan, k. al-zuhd 38, bāb șifat al-nār, no. 4318. Attributed rather to the Companion Anas b. Mālik (d. 92/710-11?) by Hannād, Zuhd i, 167; Ibn Abi 'l-Dunyā, Sifa, 59.

17 Ibn Abī Shayba, Mușannaf, k. al-zuhd 24, kalām 'Abdallāh b. 'Amr, xii, 255; similarly, Abū Nu'aym, Hilya i, 289, quoting a lost portion of Ahmad, Zuhd (addition < 'Al.); similarly, Ibn Abi 'l-Dunyā, Șifa, 58. Ibn Mas'ūd is quoted as saying, "This fire of yours takes refuge [in God] from the fire of Jahannam." See Ibn Abī Shayba, Mușannaf, k. al-janna wa-l-nār, xii, 108; likewise Mujāhid: Ibn Abi 'l-Dunyā, Șifa, 58.

18 Ibn Abī Shayba, Muṣannaf, k. al-zuhd 73, xii, 371; Aḥmad, Zuhd 16o, 163 200, 203. He is also said to have wept every time he passed by the smiths: Ibn Abī Shayba, Mușannaf, k. alzuhd 92, xii, 423 .

19 Ibn Abī Shayba, Mușannaf, k. al-zuhd 92, xii, 425.

20 Aḥmad, Zuhd 218 268; similarly, Ibn Abi 'l-Dunyā, Sifa, $72-3$. The same tradition is quoted of Sa'īd b. Jubayr (Kufan, d. 95/714?) by Qushayrī, Risāla, bāb ru'yā al-qawm fi' '-nawm, tr. Knysh, 395, cited by Gramlich, Weltverzicht 324. 
down to it." ${ }^{22}$ Ibn 'Umar (d. 73/693?) would pause to pray (yad $\left.\bar{u}\right)$ when he recited in the course of his ritual prayer a verse that mentioned hell. ${ }^{23}$ When some brethren engaged in the recollection of paradise, the Basran Mutarrif $b$. al-Shikhkhīr (d. 95/713-14) said, "I do not know what you are saying. The recollection of the Fire has come between me and the Garden" (although he is also quoted as saying that the believer's hope and fear should weigh the same). ${ }^{24}$ The Yemeni Ṭāwūs and the roasting heads that kept him awake have been mentioned before. Al-Hasan al-Bașrī recounted a conversation alluding to Q 19:71: "O brother, have you heard that you are going to the Fire?" "Yes." "Have you heard that you are going out of it?" "No." "So what is there to laugh about?" The man was not seen laughing again until he died. ${ }^{25} \mathrm{~A}$ friend came to visit the Basran 'Ațā' al-Salīmī ( $f$ l. mid-2nd/8th cent.) and found him unconscious. His wife Umm Ja'far explained, "Our neighbour lit the oven and he fell down in a faint." ${ }^{26} \mathrm{He}$ could scarcely eat or drink from thinking on Jahannam. ${ }^{27}$ 'Alī b. Fuḍayl (d. bef. 187/803), son of the famous Meccan renunciant Fuḍayl b. Tyāḍ, fainted on hearing a hadith report mentioning hell. ${ }^{28}$

The most common explanation for weeping is regret for past sins, but hell is also directly mentioned. 'Abdallāh b. Rawāha al-Anșārī (d. 8/629) wept on being called out to jihād. He explained to his wife, "By God, I have not wept from fear of death ... but rather on account of God's saying, "There is none of you who will not go down to it [Q 19:71].' I am sure I am going down to it, but I do not know whether I shall escape or not." ${ }^{\prime 29}$ Abū Hurayra (d. 58/677-8) wept in his death illness not over the world but uncertainty whether he would be taken to the Garden or the Fire. ${ }^{30}$ The Kufan Ibrāhīm al-Nakha'ì (d. 96/714?), on being found weeping, explained that he was uncertain whether the angel of

22 Ibn al-Mubārak, Zuhd no. 312; Abū Nu'aym, Hilya iv, 141; similarly, Ibn Abī Shayba, Mușannaf, k. al-zuhd 45, xii, 296. Quran translations by Jones, The Qur'ān.

23 Ahmad, Zuhd 193241.

24 Ibid., 239 293; Abū Nu'aym, Hilya ii, 202.

25 Ibn al-Mubārak, Zuhd no. 311; similarly, Ibn Abī Shayba, Mușannaf, k. al-zuhd, kalām al-Ḥasan al-Bașrī, xii, 36o. A man named al-Ghazwān, probably Syrian, reportedly resolved not to laugh until he knew whether he was bound for the Garden or the Fire. He also did not laugh until he died: Ibn al-Mubārak, Zuhd (Nu'aym) no. 324.

26 Abū Nu'aym, Hilya vi, 218. Alternatively, one might read jāriyatunā, "our serving girl."

27 Ibid., 219.

28 Ahmad, Zuhd 172215.

29 Wakī', Zuhd i, 260-1; Abū Nu'aym, Hilya i, 118-19; similarly (without mention of jihād), Ibn al-Mubārak, Zuhd nos. 309-10; Ibn Abī Shayba, Mușannaf, k. al-zuhd 26, kalām 'Abdallāh b. Rawāḥa, xii, 257; Hannād, Zuhd i, 163; Aḥmad, Zuhd 200249.

30 Ibn al-Mubārak, Zuhd (Nu'aym) no. 154; Ibn Sa'd, Biographien iv/2, 62-3 iv, 339; Ibn Qutayba, 'Uyūn ii, 309; Hilya i, 383; similarly, Ahmad, Zuhd 178223. 
death would announce he was heading for the Garden or the Fire. ${ }^{31}$ In a long comment on Q 25:63, al-Hasan al-Bașrī says that the believers weep from fear of the Fire. ${ }^{32}$ "By God, that by which they have sought the Garden does not seem great in their souls. The fear of the Fire has made them weep."33 Yazīd b. Marthad, a Damascene Follower, could scarcely eat for weeping, and made his wife and children weep with him. He explained that he would have been justified to weep continually had God merely threatened to imprison him in the bath-house (hammām) for disobedience, so how much more at the threat of imprisonment in the Fire? ${ }^{34}$ 'Abd al-Wāhid b. Zayd (Basran, d. 177/793-4?) explained that he wept from fear of the Fire. ${ }^{35}$

Some renunciants are remembered for seeking out reminders of hell. Harim b. Hayyān and the Companion Humama would go by day to the perfume market and pray to God for paradise, then go to the smiths and pray for refuge from the Fire before parting. ${ }^{36}$ The Companion Abu 'l-Dardä' (d. 32/652-3?) would blow on the fire under the pot until the tears flowed. ${ }^{37}$ The Companions Abu 'l-Dardā', Abū Hurayra, and Ibn 'Umar are all quoted as saying, "What a good house a bath is. It takes away filth and reminds one of the Fire." ${ }^{38} \mathrm{Al}$-Ahnaf b. Qays (mukhadram, d. 67/686-7?) would draw the lamp near him, then put his finger to it, saying "Feel, O Ahnaf! What carried you to doing such-andsuch today?"39 The Basran Mālik b. Dīnār (d. ca.130/747-8) would have liked to make people think constantly about hell. "By God," he said, "if I were able not to sleep, I would not sleep for fear of the descent of torment while I was sleeping. By God, if I had some helpers, I would distribute them among the minarets of the world calling out, 'O people, the Fire! the Fire! " 40 He himself was seen facing the qibla, grasping his beard and saying, "O my lord, deny Mālik's grey hairs to the Fire." 41

Ibid., 364 437; by another isnād, Ibn al-Mubārak, Zuhd no. 437; by another, Abū Nu'aym, Hilya iv, 224. Similarly, Ibn Abī Shayba, Mușannaf, k. al-zuhd 83, hadìth Ibrāhìm, xii, 397.

32 Ibn al-Mubārak, Zuhd no. 397.

33 Ibid., no. 531; but quotation in Abū Nu'aym, Hilya ii, 153, has instead "the fear of God."

34 Aḥmad, Zuhd 382 458; shorter version in Ibn al-Mubārak, Zuhd no. 481.

35 Abū Nu'aym, Hilya vi, 160-1.

36 Ahmad, Zuhd 231282.

37 Ibid., 138172.

38 Ibn Abī Shayba, Mușannaf, k. al-țahāra 131, man rakhkhașa fì dukhūl al-hammām, i, 200-1. Also attributed in a Shi'i source to 'Alī: Kulaynī, Käfì, k. al-zì wa-l-tajammul, bāb al-hammām, vi, 496.

39 Ahmad, Zuhd 235287 (addition < 'Al.).

$40 \quad$ Ibid., 319387.

41 Ibid., 325393. 
Unsurprisingly, those who behaved badly might be threatened with hell. Moses asked God why he created people whom he would torment in hell. God instructed him to sow and tend a field. When he had harvested, God asked him, "Have you left anything of it?" Moses said, "What has no good in it or I have no need of." God said, "Likewise, I do not torment anyone except one who has no good in him or of whom I have no need."42 Protracted descriptions of hell are ascribed to the mukhadram Kacb al-Ahbār (d. 34/655?), a Yemeni said to have converted from Judaism. ${ }^{43}$ The Yemeni Wahb b. Munabbih (d. 114/732-3?) is recalled as quoting the prophet David, "My lord, I have no patience with the heat of your sun, so how can I be patient with your Fire? My lord, I have no patience with the sound of your mercy (meaning thunder), so how can I be patient with the sound of your torment? ${ }^{44} \mathrm{Abu}$ Bakr (d. 13/634) is quoted as warning, "Do not hold God in contempt, lest he cast you down in the Fire on your face", with allusion to Q 27:90, "Those who come with evil will be cast face first into the Fire." ${ }^{\prime 5}$ The Companion Abū Mūsā al-Ash'arī (d. 50/670-1?) said, "Whoever follows the Quran, it will drop him in the pastures of the Garden. Whomever the Quran follows, it will throw him down on his nape, then hurl him into Jahannam." ${ }^{46}$ Abū Hurayra advised a daughter, "Do not wear something decorated with gold, for I fear for you the flame (mudhahhab, lahab). Do not wear silk, for I fear for you the fire (harir, hariq)." ${ }^{\prime 47}$ The Basran Bakr b. 'Abdallāh al-Muzanī (d. 106/724-5?) warned, "Who sins laughing will enter the Fire weeping." ${ }^{\prime 48}$ The Basran Muhammad b. Wāsic (d. 123/740-1) said he had heard that someone who himself failed to do as he had commanded and forbidden others to do would be thrown into the Fire, where his intestines

42 Ibid., $87-8$ 110-11.

43 E.g., Ibn Abī Shayba, Mușannaf, k. al-zuhd 73, xii, 385-6 (faces to be blackened or whitened, and so on); Abū Nu'aym, Hilya v, 368-71 (a series of stories in which 'Umar asks of Ka'b, "Make us afraid," to which he responds with descriptions of paradise and hell); ibid., vi, 10-12 ('Īsā describes the seven levels of hell that he was allowed to see); ibid., vi, 37-42 (God details to Mūsā the rewards and punishments due various categories of the obedient and disobedient). For Ka'b's conversion, see Ibn Sa'd, Biographien vii/2, 156 vii, 445 . Ahmmad, Zuhd 71 9o. Although less often than Ayyūb, David is sometimes credited with being the most patient of people: Ibid., 84106 .

45 Ibid., 110137.

46 Ibn Abī Shayba, Mușannaf, k. al-zuhd 37, kalām AbīMūsā, xii, 279.

47 Aḥmad, Zuhd 153192 (addition < 'Al.).

48 Abū Nu'aym, Hilya ii, 229, vi, 185, quoting a lost portion of Ahmad, Zuhd (addition < 'Al.). 
would be drawn about him as turns a mill stone. ${ }^{49}$ The Damascene Bilāl b. Sad (d. bef. 125/743) warned, "Many a man is mistakenly pleased, not realizing that as he eats, drinks, and laughs, by God's decree he is rightly fuel for the Fire." ${ }^{50}$ The Basran Abū 'Imrān al-Jawnī (d. 128/745-6?), recalled, "We were in the mosque when a shaykh stood up before us and said, 'By God, O people of the mosque, God will certainly use you to complete the number of the people of the Garden or the number of the people of the Fire', making us weep." ${ }^{51}$ One 'Abd al-Rahmān b. Mikhmar warned from the minbar, "Woe betide the one who gathers but keeps his gains from people.... They will carry him to a valley in Jahannam called Law."52 (Law here is probably the Arabic particle used in its optative sense, as in, say, awaddu law akūnu sakhiyyan, "Would that I were generous." Compare the Prophet's saying, "Beware of law, for it opens up the work of Satan.") ${ }^{53}$

Renunciant literature also quotes not preachers but experimenters in contemplating hell for themselves. Ibrāhīm al-Taymī (Kufan, d. 92/710-11) recounted,

I imagined my soul in the Fire, experiencing its boiling and flaming, eating of its zaqqüm (Q 37:62, 44:43, 56:52) and drinking of its zamharìr (Q 76:13). I said to my soul, "O soul, what do you wish?" It said, "Return to the world and do a deed by which I may escape from this punishment." Then I imagined my soul in the Garden with its houris, wearing its sundus, its istibriq (Q 18:31, 44:53, 76:21), and its silk. I said, "O soul, what do you wish?" It said, "Return to the world and do a deed such that I can have more of this reward." I said, "You are in the world and safe."

Yazīd b. Abān (Basran qāsș, d. bef. 120/737-8) made himself thirsty in the Basran heat for forty years. He said to his companions, "Come, let us weep over cold water" (presumably contemplating the torment of hell). 55 "Abd al-Wāhid b. Zayd similarly called for his brethren to weep over cold water in

\footnotetext{
49 Aḥmad, Zuhd 377451.

5o Ibid., $385^{-6} 462$ (addition < 'Al.).

$51 \quad$ Ibid., 313380 (addition < 'Al.).

52 Abū Dāwūd, Zuhd 26o, no. 519 (Syrian isnād).

53 Among other places, Muslim, Șaḥịh, al-qadar, bāb bayān anna al-äjāl..., no. 6774; Ibn Māja, al-muqaddima 1o, bāb fi 'l-qadar, no. 79; ibid., al-zuhd 14, bāb al-tawakkul, no. 4168. For the grammar, see Wright, Grammar ii, 347-8.

54 Ahmad, Zuhd 363434 (addition < 'Al.).

55 Ibn Qutayba, 'Uyūn ii, 297; Abū Nu'aym, Hilya iii, 5o. Cf. also a report that the Basrans Budayl (d. 130/747-8?), Shumayț or Sumayt, and Kahmas (d. 149/766-7?) met together in
} 
this world, hoping it might be served them in the afterlife. ${ }^{56}$ Dāwūd al-Ṭāī (Kufan, d. 165/781-2?) repeated all night a verse of the Quran that mentioned hell. By morning he was ill and remained so for days, until he was found dead. ${ }^{57}$ Saīd b. 'Abd al-'Azīz, for whom hell was always prepresented, has been mentioned before.

Al-Muhāsibì (Basran, d. Baghdad? 243/857-8) is the most famous theorist of renunciation. He calls for contemplation (tafakkur) of hell and describes it at some length in his main work, al-Ricāya li-ḥuqūq Allāh.

When he thinks about the threat to frighten himself of the great extent of his punishment, when the extent of the torment becomes great in his heart, then fear rages such as he cannot control.... As the one feeding the fire adds fuel below the boiling pot, the longer the fuel lasts, the fiercer is the boiling. So likewise the servant: so long as thinking to make himself fear the punishment, the number of the terrors, and the great questioning, along with knowing how great a claim God has and how it is incumbent to obey him, whereas he has wasted that, his fear rages. ${ }^{58}$

In al-Ba'th wa-l-nushūr, on the Resurrection, al-Muhāsibī restricts his discussion to the terrors of the Last Judgement, not actually hell.59 (Many renunciant sayings stress terror at the prospect precisely of standing before God at the Last Judgement rather than hell. A leading advantage of the doctrine of purgatorial pains, "the torment of the tomb", is that it allows Muslims to be threatened with punishment while maintaining the dogma that all Muslims will be saved. Nevertheless, references to purgatorial pains in early renunciant literature are rare. See for example a story from the Kufan 'Amr b. Shurahbill [d. 63/682-3] of an outstandingly scrupulous man who was surprised, after dying, to find himself flogged and his grave consumed by fire. It was explained that he had once performed a ritual prayer without duly renewing his ritual

the house of one of them and said, "Come, today, for us to weep over cold water." See Abū Nu'aym, Hilya vi, 213, quoting a lost portion of Ahmad, Zuhd (addition < 'Al.).

56 Abū Nu'aym, Hilya vi, 161.

57 Ibid., vii, 340. There is also a story of his being found inside on a hot evening, even though his house was as hot as a bath. At first he ignored his visitors' complaining, then he ordered them to go out into the court. There he reminded them of some Quranic torments, especially being struck by hooked iron rods (maqāmic, with allusion to Q 22:21). After this he lost consciousness, whereupon his guests left: Saymarī, Akhbār, 110.

$5^{8}$ Muhāāibī, Ri‘āya, 2971.

59 Muḥāsibī, Ba'th. 
purity and forborne to help a poor man who had importuned him. ${ }^{60}$ In Kitāb al-Tawahhum, al-Muhāsibī calls for imagining death, being called to assembly at the Last Judgement, and the torment of the condemned, among other things, although these terrors are balanced by an equally long section on the attractions of paradise. "Imagine your passing over the bridge in severity of terror and weakness of body, even if you should have fainted, being unforgiven, without knowing whether your foot had slipped from the path."61

It must be conceded, however, that contemplation of death comes up more often than of hell. The Prophet, on hearing Companions praising someone, asked, "How is his recollection of death?" They said, "He is not like that." Prophet: "Then he is not as you say." ${ }^{2}$ The Prophet said to one of the anșār, "I commend to you the recollection of death, for it will make you forget the matter of the world." ${ }^{3}$ Abu 'l-Dardā' said, "Whoever recollects death, his envy diminishes and likewise his joy" 64 "Consider yourselves among the dead" was some of his advice. ${ }^{65}$ Sa'd b. Abī Waqqāṣ (Companion, d. 55/674-5) told his son, "When you wish to pray, perform the ritual ablution well and pray such a prayer as if you think you will never pray another after it." ${ }^{\prime 6}$ Al-Rabī' b. Khuthaym (Kufan, d. 63/682-3?) advised, "Often remember this death whose like you have never before tasted." 67 "If recollection of death departed from my heart for a moment (sā'atan), it would be corrupted." ${ }^{\prime} 8$ Yazìd b. Sharīk (Kufan, d. 65-86/685-705) or his son Ibrāhīm (d. 92/710-11) was unable to have sex with his wife from recollection of death. ${ }^{69}$ Many more examples might be quoted. ${ }^{70}$ It is difficult to be certain, but the recollection of death seems to be recommended chiefly

6o Ibn Abī Shayba, Mușannaf, k. al-zuhd 45, xii, 296-7. For examples of terror at the prospect of standing before God, see Melchert, Exaggerated fear 287-8, 290-4.

61 Muhāsibī, Tawahhum 415.

62 Ahmad, Zuhd 17 24, with an isnād that skips from Sufyān b. 'Uyayna to the Prophet.

63 Nu'mān, Da'ä’im i, 221. Similarly, the Prophet on the best of people: "The one who most recollects death is the readiest for it." See ibid., i, 221. Da'ä'im al-islām is mainly a book of law, not renunciation; however, we have no alternative sources for early Ismā̄illi piety, and it illustrates the pervasiveness of renunciant piety that a book of laws should include a section on dhikr al-amr bi-dhikr al-mawt.

64 Ibn Abī Shayba, Mușannaf, k. al-zuhd 13, kalām Abi'l-Dardä', xii, 219; similarly, by two alternative asānìd, Abū Nu'aym, Hilya i, 220; similarly, Ibn al-Mubārak, Zuhd (Nu'aym) no. 149.

65 Ibn al-Mubārak, Zuhd no. 1155; Aḥmad, Zuhd 134-5 168.

66 Ibid., 182227.

67 Abū Nu'aym, Hilya ii, 114.

68 Ibid., ii, 116.

69 Ibid., iv, 210.

70 For some, see Gramlich, Weltverzicht $140-5$. 
for the sake of two aims. First, it should promote detachment from the world, since one will not remain in it for long. Secondly, it should promote fervent devotions, since one dare not depend on accumulating credit in the future. It thus overlaps with exhortations to restrict one's plans and hopes to the short term (qișar al-amal).

Indeed, fairly few sayings about hell dwell on such details as are to be found in the Quran. "On the day when [the gold and silver] will be heated up in the fire of Jahannam and their foreheads, sides and backs will be branded with them" (Q 9:35a). "Behind him is Jahannam, [where] he is given pus-like water to drink. He sips it but can hardly swallow it" (Q 14:16-17a). "We have prepared for the wrong-doers a fire, whose pavilion encloses them. If they ask for showers of rain, they will receive showers of water like molten copper which will roast their faces. How evil a drink; how evil a resting-place" (Q 18:29). And so on and so on. Renunciant literature does sometimes quote glosses on the terrors of hell. For example, Muțarrif b. al-Shikhkhīr explained of Q 37:55 ("He looks down and sees him in the midst of hell"), "He saw them with boiling skulls. ..."71 But such quotations are surprisingly hard to find.

\section{$4 \quad$ The Extent of Renunciant Interest in Hell}

Content analysis shows that renunciant literature is highly miscellaneous. Analysis of a sample of 163 items randomly chosen from Ibn al-Mubārak, alZuhd, recension of al-Husayn al-Marwazī, shows that recommendations of ritual prayer constitute the category best represented. Restricted eating and drinking is mentioned about half as often, likewise hell and paradise, each with about 5 percent of all items. This shows that hell, while far from being the principal thing renunciants talked about (or at least that collectors of renunciant sayings put down), was something they thought about as often as almost anything else. ${ }^{72}$ The recension of Nu'aym b. Hammād includes 436 items not in that of al-Husayn al-Marwazī. Both recensions feature topical arrangement but only Nu'aym's has separate sections on paradise and hell. The section on

\footnotetext{
71 Abū Nu'aym, Hilya ii, 201.

72 Cf. a content analysis of items quoted of Aḥmad b. Ḥanbal, al-Zuhd: "In a content analysis of a random sample of 117 quotations from Abū Nu'aym, the category best represented is rejection of worldly goods... This is followed by items praising particular individuals in fairly general terms.... Of ritual activities, prayer (șaläh) is the single one most often commended; of austerities, restricted eating and drinking." See Melchert, Ahmad ibn Hanbal's book 358 .
} 
the description of paradise runs nos. $227-85$ ( 59 items, $5 \%$ or less), while the section on the description of hell runs nos. $286-346$ ( 61 items, $5 \%$ or less). ${ }^{73}$ Hannād b. al-Sarī, al-Zuhd, is likewise arranged topically and includes sections on paradise and hell. It appears to have somewhat more on paradise and hell than other collections, the section dealing with the former comprising nos. 9-194 (186 items, $13 \%$ of the whole book), the latter nos. $205^{-319}(115,8 \%$ of the total).

Ibn Abī Shayba, al-Mușannaf, includes 800 items in a kitāa al-du'äa within. In a randomly-chosen sample of 100, only one mentions hell: "Protect us from the torment of the Fire."74 One in the sample mentions "Your torment of the unbelievers", two paradise. The Musannaf also includes about 1,500 items in a kitāb al-zuhd within, presenting very much the same sort of material as fills up the Zuhd books attributed to Ibn al-Mubārak and Aḥmad. Ibn Abī Shayba concentrates sayings about paradise and hell in a separate book, though, comprising the three subsections mä dhukira fi' 'l-janna ("what has been said of the Garden") with 165 items, mä dhukira fi 'l-nār ("what has been said of the Fire") with 83, and mà dhukira fi sa'at rahmat Allāh ("what has been said of the wideness of God's mercy"), with 28 . If the section on hell were added to the book on renunciation, it would comprise about 5 percent of the total. Thus, sections on paradise and hell are either in balance (Ibn al-Mubārak as collected by Nu'aym) or the one on paradise preponderates (Hannād, Ibn Abī Shayba).

Quranic glosses seem to be unusually prominent in these sections on hell. They comprise 30 percent of the section on hell in Nu'aym's additions to the Zuhd, 22 percent of all of Nu'ayms additions. To a yet greater extent, the proportion of Quranic glosses in Hannād's section on hell is higher than in the book as a whole, $5^{1}$ percent as opposed to 9. Quranic glosses make up 30 percent of Ibn Abī Shayba's chapter on hell, 11 percent of his kitāb al-zuhd. There is some overlap with the literature of Quranic commentary. For example, of 59 explanations from Hannād of Quranic passages describing hell, 35 (59\%) are also in al-Ṭabarìs Quran commentary.

73 "Or less" requires a gloss. The editor does not tell us how many items make up Nu'aym's collection. It must include at least the 436 numbered items at the end plus the 650 or so in al-Husayn's recension for which he remarks textual variants in Nu'aym's. Five percent of Nu'aym's recension represents a maximum estimate, based on the assumption that only items in al-Husayn's recension for which the editor remarks textual variants are also in Nu'aym's.

74 Ibn Abī Shayba, Muṣannaf, k. al-du'ầ 3o, man yuhibbu idhā da'ā an yaqūla rabbanā..., $\mathrm{x}, 59$. 
Given many shocking images of hell in the Quran, I thought to look up the three passages quoted above about the terrors of hell in al-Ṭabarìs Quran commentary to see whether there were any typical differences. Regarding the first, Q 9:35a, al-Tabarī begins with some paraphrases of his own. Then he quotes the Companion Abū Dharr by a Basran isnād: "Give those who store up treasure tidings of branding (kayy) on the forehead, branding on the side, and branding on the back, until the heat penetrates to the interior." Next come three more stories, again with Basran isnāds, in which an anonymous man in rough clothing preaches the same message in the mosque of Medina. In one version, his hearers react sullenly, for which he rebukes them: "They do not understand."75

Al-Tabari’s treatment of the next passage, Q 14:16-17a, likewise begins with comments from al-Ṭabarī, first glosses of words, then grammatical explanations. He says that $m \bar{a}^{\text {}}$ șadìd ("pus-like water" in Jones's translation) means pus and blood. This is followed by quotation of those who said so: Mujāhid, by three isnāds, then Qatāda by two, saying it means "what runs from his flesh and skin", then al-Ḍaḥ̣āk, saying it means "what comes from the interior of the unbeliever, a mixture of pus and blood." Finally, he quotes an elaboration from the Prophet of the next phrase: "When he drinks it, it cuts up his intestines until they come out of his rear."76 None of these, on Q 9:35a and 14:16-17a, have I found in collections of renunciant sayings, including the last, although it has Ibn al-Mubārak in the isnād. A partial exception is a gloss not quoted by al-Ṭabarī that appears in Ibn Abī Shayba, kitāb al-janna wa-l-nār (not al-zuhd), from al-Hasan al-Bașrī: "If a bucket of the șadìd of Jahannam were poured from heaven so that its odour reached the people of the earth, it would spoil the world for them." 77

Tabarīs treatment of Q 18:29 begins not with philological notes but a discussion of predestination, quoting with isnāds Ibn 'Abbās, Mujāhid, and Ibn Zayd. Then he quotes three glosses on șurädiq ("pavilion" in Jones's translation): a wall of fire according to Ibn 'Abbās, smoke according to an anonymous man, and an ocean according to the Prophet. Then comes the story of Ibn Mas'ūd and the treasury to introduce six glosses on muhl ("molten copper" in Jones's translation).${ }^{78}$ I have found one of these items in major collections of renunciant sayings, namely the story of Ibn Mas'ūd — the rest not. (By comparison,

Ṭabarī, Jāmic vi, 363, ad Q 9:35.

76 Ibid., vii, 428-30, ad Q 14:16-17.

77 Ibn Abī Shayba, Mușannaf, k. al-janna wa-l-nār 2, mā dhukira fìmā u'idda li-ahl al-nār, xii, 108. Ibn Abi 'l-Dunyā offers a slightly different version: "There would be no one left on the face of the Earth but who had died" (Șifat al-nār, 38). 
al-Ṭabarī's younger contemporary al-Māturīdī [d. 333/944-5] devotes as much space to glosses and paraphrases but usually quotes his authorities anonymously, never with isnāds, and more often summarizes. For example, he says of Q 18:29 that most say muhl means the dregs of oil or juice. Some say the point of comparison is its thickness, some its blackness, al-Ḥasan and Abū Bakr its mixing different colours. $)^{79}$

I also tried the reverse for one gloss from Ibn al-Mubārak. With an Egyptian $i s n \bar{a} d$, he quotes the Prophet as saying, "If a bucket of ghislin were poured out in the world, it would befoul the people of the world." ${ }^{80}$ This glosses a word in Q 69:36 ("Nor any food except filth"). Țabarī first glosses it by saying some Basrans describe ghislin as what flows from a wound or the anus. With an isnād, then, he gives Ibn 'Abbās' gloss that it means șadìd, "serum"; by another isnād that Ibn 'Abbās said it was what came out of their flesh; by an isnād from Qatāda that it means the worst, foulest, and most revolting food; and finally by an isnād from Ibn Zayd that no one knows what ghislīn and zaqqūm are. ${ }^{81}$ Oddly, he quotes the hadith report through Ibn al-Mubārak not here but apropos of Q 78:25: "If a bucket of ghassāq were poured out in the world, it would befoul the people of the world." ${ }^{2}$ The version with ghassāq instead of ghislin also appears in the hadith collections of al-Tirmidhī and Ahmad, perhaps confirming the sensibleness of Ibn Zayd's agnosticism; that is, suggesting that the interpretation of these torments of hell was fairly arbitrary. ${ }^{83}$ The similarity

79 Māturīdī, Ta’î̀̄lāt, v, 363-4, vi, 377-8, vii, 167, ad Q 9:35, 14:16-17, 18:29.

8 o Ibn al-Mubārak, Zuhd (Nu'aym) no. 316c. Also apud Asad, Zuhd 61, not through Ibn al-Mubārak but through his shaykh, Ibn Lahī‘a.

81 Țabarī, Jāmic xii, 221-2, ad Q 69:36.

82 Ibid., xii, 407, ad Q 78:25. Quoted of the Prophet by Asad ibn Mūsā, Zuhd 61. Ghassāq is the reading favoured by the Kufan readers Ḥamza and al-Kisāà', also 'Āṣim according to one riwāya. The rest of the seven favour ghasāq. Ghassāq/ghasāq also occurs at Q 38:57, on which occasion al-Ṭabarī provides yet more glosses but not the hadith report through Ibn al-Mubārak. Hannād b. al-Sarī offers three glosses, from 'Ațiyya (b. Sacd, Kufan, d. 111/72930), Mujāhid, Abū Razīn (Mas'ūd b. Mālik, Kufan, d. 85/704-5), and Abū 'l-Āliya (Basran, d. 9o/807?), only the last of whom is the least prominent as a renunciant: Hannād, Zuhd i, 186-7. Ibn Abi 'l-Dunyā quotes in turn the Prophet and Ibn 'Abbās (by Egyptian and mixed Kufan/Meccan isnāds, respectively): "If a bucket of ghassā $q$ were poured out in the world, it would befoul the people of the world" (Șifat al-nār, 37-8). Admittedly, Ibn Abī Shayba does include a gloss on ghassāq as it appears in Q 78:25 from the Kufan Ibrāhīm al-Nakha'î in his k. al-zuhd: "It is what drips from their skins and flows from their scrapes (bashr)." See Ibn Abī Shayba, Mușannaf, k. al-zuhd 83, hadīth Ibrāhīm, xii, 397. Ibrāhīm is most famous as a jurisprudent but renunciant sayings are also often quoted of him.

83 Tirmidhī, Jāmi', șifat jahannam 4, bāb mā jāà fì șifat sharāb ahl al-nār, no. 2584; Ahmad, Musnad iii, 28, 83 xvii, 231-2, xviii, 310-11. 
to al-Hasan's reported comment on șadid suggests that the identification of speakers might also be arbitrary.

Here are al-Tabarīs leading authorities in descending order of frequency of citation: ${ }^{84}$

1. Mujāhid b. Jabr, Meccan (d. 103/721-2?);

2. Qatāda b. Di'āma, Basran (d. 117/735-6?);

3. 'Abdallāh b. 'Abbās, Companion (d. Ta'if, 68/687-8);

4. $\quad$ al-Suddī, Kufan (d. 127/744-5);

5. al-Ḥasan al-Bașrī;

6. 'Abd al-Raḥmān b. Zayd b. Aslam, Medinese (d. 182/798-9);

7. al-Ḍaḥ̣āk b. Muzāḥim, Kufan (d. 106/724-5?);

8. Muhammad the Prophet;

9. Saīd b. Jubayr, Kufan (d. 95/714?);

10. 'Abdallāh b. Mas'ūd, Companion;

11. 'Ikrima b. 'Abdallāh, Medinese (d. 107/725-6?).

$\mathrm{Al}$-Hasan is very prominent in renunciant literature and had a high reputation as a preacher. Al-Jāhiz, who should have been an expert judge, states, "As for orations (khutab), we do not know of anyone who came before al-Hasan al-Bașrī in them." ${ }^{85} \mathrm{He}$ expressly identifies both al-Hasan and his brother Sa'ìd as early qușșasṣ. ${ }^{86}$ One might have expected the qușsass, popular preachers in the mosques, to have delighted in elaborating on the torments of hell. An example has been quoted from the obscure 'Abd al-Rahmān b. Mikhmar. By and large, however, this is not the part of their preaching that made its way into the specialized literature of renunciation. Of the foregoing eleven names, six rate separate sections in Ibn Abī Shayba's kitāb al-zuhd, for example, but the rest do not (including a majority of the Followers on the list). The section devoted to al-Ḥasan al-Bașrī in Ahmad, al-Zuhd includes 228 sayings, including glosses on 30 verses of the Quran. Two of those glosses have to do with hell: how often people in hell will have their skins burnt off and replaced, as promised in Q 4:56, and the length of the ahqua $b$ in Q 78:23. ${ }^{87}$ It appears again that it was not the leading renunciants of the early eighth century who dominated the elaboration of Quranic descriptions of hell.

$84 \quad$ Based on an unpublished paper by Ismail Lala.

85 Al-Jāhịiz, Bayān i, 354.

86 Ibid., 367. Al-Hasan and his Kufan contemporary Saīid b. Jubayr are especially remarked for preaching (kāna al-Hasan yaquṣṣ) in Ahmad, Zuhd 215264 (addition < 'Al.)

87 Ibid., 269329 (addition < 'Al.), 288351. 
Quran commentary is closer to the tradition of adab than to that of zuhd, as shown by al-Ṭabarî's interest in philology and grammar. Ibn Abi 'l-Dunyā, Sifat al-nār, comprises 259 items (by the editor's count, excluding a few long descriptions from an unnamed contemporary), all of them of course having to do with the description of hell; that is, over twice as many as in the section on hell in Hannād, al-Zuhd, four times as many as in the section on hell in Ibn al-Mubārak, al-Zuhd (recension of Nu'aym). Forty-two percent of all items are glosses on the Quran. However, it might be a mistake to generalize from al-Ṭabarī and Ibn Abi 'l-Dunyā about greater interest in hell in the tradition of adab. Abū 'Ubayd (d. 224/838-9?), al-Khuțab wa-l-mawā'iz, comprises 145 items from prophets, early scriptures, and the last prophet's Companions. Just one mentions hell: "I have not seen the like of the Fire, the one fleeing which is asleep, nor the like of the Garden, the one seeking which is asleep."88 (I take it this is a joke- the Fire should be sufficiently frightening that no one can sleep who is threatened by it, the Garden sufficiently attractive that no one can sleep who has a chance of gaining it.) ${ }^{89}$ Ibn Qutayba (d. 276/889?), Uyūn al-akhbār, includes a section on renunciation comprising about 400 items. I have noticed very few that mention hell. One quotes al-Khansā', a poetess who survived into the Islamic period: "I used to weep over Șakhr because of his being killed, but now I weep over him on account of the Fire." Another quotes Abu 'l-Dardā' as saying that three things make him laugh and three weep, the last of those making him weep being the thought of standing at the Last Judgement before God, not knowing whether he will go to the Garden or the Fire. ${ }^{90}$ Yet another has been noted above, namely Abū Hurayra's weeping over uncertainty whether he will be taken to the Garden or the Fire. These do not constitute a major presence, nor is there any lurid elaboration on Quranic torments.

Al-Tha'labì (d. 427/1035-6), Qatlā'l-Qur'ān, collects stories of persons (about twenty in all; in one case jinn) who died on hearing the Quran recited or on contemplating it. For a few, he provides multiple versions. Most stories include quotations of particular lines. They might be as harmless as "Little of the night

88 Abū 'Ubayd, Khuțab, 101-2; also reported by Tirmidhī, Jāmi', abwāb șifat Jahannam 10, no. 2601; Ibn al-Mubārak, Zuhd no. 27. Alternatively attributed to Harim b. Ḥayyān: Ibn al-Mubārak, Zuhd no. 28; Ibn Sa'd, Biographien vii/1, 95 vii, 132; Ibn Abī Shayba, Mușannaf, k. al-zuhd 85, xii, 407; Aḥmad, Zuhd 231283 (addition < 'Al.); Abū Nu'aym, Hilya ii, 119, quoting a lost portion of Ahmad, Zuhd (addition < 'Al.). Similarly attributed to 'Āmir ibn 'Abd Qays, Basran (d. ca. 55/674-5). See Hannād, Zuhd i, 291.

89 By contrast, Ibn Abi 'l-Dunyā quotes a straight version going back to the Prophet: "The one fleeing the Fire does not sleep, nor the one seeking the Garden. Do your utmost in seeking paradise and your utmost in fleeing the Fire." See Ibn Abi 'l-Dunyā, Șifa, 14. 
they used to slumber" (Q 51:17) ${ }^{91}$ An anonymous Basran shaykh was deeply disturbed to hear the verse,

Say, "The truth is from your Lord. Let whoever wishes believe and whoever wishes be ungrateful. We have prepared for the wrong-doers a fire, whose pavilion encloses them. If they ask for showers of rain, they will receive showers of water like molten copper which will roast their faces. How evil a drink; how evil a resting-place" (Q 18:29).

He asked whether there was any relief. Yes, said the reciter, and recited the verse, "Say, ' $\mathrm{O}$ my servants who have been prodigal against yourselves, do not despair of God's mercy. God can forgive sins altogether. He is the Forgiving, the Compassionate' " (Q 39:53), whereupon the shaykh cried out and died. ${ }^{92}$ (He may have recalled the next verse, "Turn in penitence to your Lord and submit to Him before the torment comes to you", encouraging him to quit this life at once to avoid any chance of backsliding.) Altogether 33 verses are mentioned, by my count, of which nine mention hell or at least punishment. The Quran might terrify in many ways, then, including but not exclusively by threatening the unbelievers with hell.

Hell is a threat to discourage misbehaviour. To this end, the Quran continually refers to it. One might expect it to be prominent in the literature of renunciation, directed as it is to encouragements to piety. Yet I have found less there on hell than I expected. Much as renunciants liked to recite the Quran, much as they contemplated it, they did not characteristically elaborate on its vivid descriptions of punishments in the afterlife. They generally preferred, rather, to commend the contemplation of death. Hell may easily be contemplated in a spiritually dubious manner, out of schadenfreude or voyeuristic sadism. I remember going to an exhibit of drawings by Botticelli to illustrate The Divine Comedy. The first gallery, with drawings of hell, was inconveniently full; the crowd was noticeably thinner in the second gallery, with drawings of Purgatory; and my wife and I almost had to ourselves the last gallery, with drawings of Heaven. The crowd was by and large unsympathetic to Botticelli's scheme of uplift. There is more detail on the torments of hell in both prophetic hadith

\footnotetext{
91 Tha labì, Qatlā 81 (Ger.), 141 (Ar.).

92 Ibid., 83-4 (Ger.), 146 (Ar.).
} 
and Quranic commentary than in the renunciant literature. It is certainly no rule that the compilers of renunciant sayings avoided all elaborations of Quranic descriptions of hell without implications for how to live better. On the whole, however, the compilers of renunciant sayings seem to have shown wise restraint in limiting what they related about hell.

\section{Bibliography}

\section{$1 \quad$ Sources}

'Abd al-Razzāq: al-Mușannaf, ed. Ḥabīb al-Rahmān al-A'ẓamī, Min Manshūrāt al-Majlis al-'Ilmī 39, 11 vols, Johannesburg 1390-2/1970-2.

Abū Dāwūd: K. al-Zuhd, ed. Mușṭafā Maḥmūd Ḥusayn, Tanta 1424/2003.

Abū Nu'aym: Hilyat al-awliyā’, 10 vols, Cairo: Maktabat al-Khānjī, 1352-7/1932-8.

Abū 'Ubayd: al-Khuțab wa-l-mawāizz, ed. Ramaḍān 'Abd al-Tawwāb, Maktabat Abī 'Ubayd al-Qāsim b. Sallām 1, Cairo 1406/1986.

Ahmad b. Hanbal: K. al-Jāmi' fi 'l-ilal wa-ma'rifat al-rijäl, ed. Muhammad Ḥusām Bayḍūn, 2 vols, Beirut 1410/1990.

——: Musnad imām al-muhaddithīn, 6 vols, Cairo 1313/1895. Also Musnad al-imām

A ḥmad b. Hanbal, ed. Shu'ayb al-Arna’ūt, et al., 50 vols, Beirut 1413-21/1993-2001.

References to latter edition in italic.

— al-Zuhd, Mecca 1357, repr. Beirut 1396/1976. Also repr. with different pagination Beirut 1403/1983. References to latter edition in italic.

Asad b. Mūsā: K. al-Zuhd, ed. Raif Georges Khoury, Wiesbaden 1976.

al-Bayhaqī: K. al-Zuhd al-kabìr, ed. 'Āmir Ahmad Ḥaydar, Beirut 1408/1987.

al-Bukhārī: al-Jāmi' al-șahịh, numbering of 'Abd al-Bāqī, first published in Ibn Ḥajar,

Fath al-bārì, ed. Muhibb al-Dīn al-Khațīb, 14 vols, Cairo 1380/196o.

al-Dārimī: Sunan al-Dārimī, ed. Muhammad Aḥmad Dahmān, Damascus 1349.

al-Dhahabī: Tārīkh al-islām, ed. 'Umar 'Abd al-Salām Tadmurī, 52 vols, Beirut 140721/1987 2000 .

Hammām b. Munabbih (attr.): Șahịfa, ed. Muhammad Ḥamīd Allāh, in RAAD 28 (1953/1372-3), 96-116, 270-81, 443-67.

Hannād b. al-Sarī: K. al-Zuhd, ed. 'Abd al-Raḥmān b. 'Abd al-Jabbār al-Faryawā'ī, 2 vols, Kuwayt 1406/1985.

Ibn Abi 'l-Dunyā: Kitāb Șifat al-nār, ed. Mus'ad 'Abd al-Ḥamīd Muhammad al-Sa'dānī, Cairo 2000.

Ibn Abī Shayba: al-Mușannaf, ed. Ḥamad b. 'Abdallāh al-Jum'a and Muḥammad b. Ibrāhīm al-Luhaydān (Lahịdān?), 16 vols, Riyadh 1425/2004.

Ibn al-Mubārak: al-Zuhd wa-l-raqāì, ed. Ḥabīb al-Rahmmān al-A'ẓamī, Malegaon 1386.

Repr. with different pagination Beirut 1419/1998. References to the section from al-Husayn b. al-Hasan unless otherwise noted. 
Ibn Māja: al-Sunan, ed. Muḥammad Fu'ād 'Abd al-Bāqī, 2 vols, Cairo 1952-4. Ibn Qutayba: 'Uyūn al-akhbār, 4 vols, Cairo 1343-9/1925-30.

Ibn Sacd: Biographien, ed. Eduard Sachau et al., 9 vols in 15, Leiden 1904 40. Repr. with different pagination as al-Ṭabaqāt al-kubrā, 9 vols, Beirut 1957-68. References to latter edition in italic.

al-Jāḥiz: al-Bayān wa-l-tabyīn, ed. 'Abd al-Salām Muḥammad Hārūn, Maktabat al-Jāḥiz 2, 4 vols in 2, Cairo, 1467/1948.

Jones, Alan (tr.): The Qur'ān, n.p. 2007.

al-Kulaynī: al-Kāfì, ed. 'Alī Akbar al-Ghaffārī, corrected by Muhammad al-Ākhundī, 8 vols, Tehran 1389-91/[1969-71].

Mālik: al-Muwațta', riwāayat Yahyā b. Yahyyā al-Laythī al-Andalusī, ed. Bashshār 'Awwād

Ma'rūf, 2 vols, Beirut 1417/1997.

al-Māturīdī: Ta’wìlāt ahl al-sunna, ed. Majdī Būsallūm, 10 vols, Beirut 2005/1426.

al-Muḥāsibī: al-Ba'th wa-l-nushūr, ed. Muḥammad 'Īsā Rị̣wān, Beirut 1406/1986.

—_ al-Ri āyya li-ḥuqūq Allāh, ed. Margaret Smith, E.J.W. Gibb Memorial, new ser. 15, London 1940. Also ed. 'Abd al-Qādir Aḥmad 'Ațā, 4th edn., Beirut n.d. Reference to latter edition in italic.

: K. al-Tawahhum, with al-Wașāyā, ed. 'Abd al-Qādir 'Ațā, Beirut 1406/1986.

Muslim: al-Ṣaḥ̄h, ed. Muhạmmad Fu’ād 'Abd al-Bāqī, 5 vols, n.p. 1374-5/1955-6.

al-Nu'mān, al-Qāḍī: Da'ẩim al-islām, ed. Asaf Ali Asghar Fyzee, 2 vols, Cairo 1379-83/1960-3.

al-Qushayrī: Al-Risāla, tr. Knysh, A.D.: Al-Qushayri's epistle on Sufism, rev. Muhammad Eissa, Great books of Islamic civilization, Reading 2007.

al-Ṣaymarī: Akhbār Abī Hanīfa wa-aṣhāaih, Silsilat al-mațbū'āt 13, Hyderabad 1394/1974, repr. Beirut 1976.

al-Ṭabarī:Jāmi' al-bayān fì ta’wīl al-Qur'ān, 31 vols, Cairo 1321, repr. with new pagination 13 vols, Beirut 1420/1999.

al-Tha'labī, Qatlā = Die vom Koran Getöteten. At-Ta labīs Qatlā l-Qurān nach der Istanbuler und den Leidener Handschriften, ed. and tr. Beate Wiesmüller, Arbeitsmaterialien zum Orient 12, Würzburg 2002.

al-Tirmidhī: al-Jāmic al-ṣaḥ̄ḥ, ed. Aḥmad Muhammad Shākir et al., 4 vols, Beirut n.d. Wakī' b. al-Jarrāḥ: K. al-Zuhd, ed. 'Abd al-Raḥmān 'Abd al-Jabbār al-Faryawā'̀̄, 3 vols, Medina 1404/1984.

\section{$2 \quad$ Studies}

Gramlich, R.: Weltverzicht: Grundlagen und Weisen islamischer Askese, Veröffentlichungen der Orientalischen Kommission 43, Wiesbaden 1997.

Katz, M.H.: Body of text: The emergence of the Sunni law of ritual purity, sunY series in medieval Middle East history, Albany 2002. 
Melchert, Ch.: Aḥmad ibn Ḥanbal's book of renunciation, in Der Islam, 85 (2008), 345-59.

: Exaggerated fear in the early Islamic Renunciant Tradition, in JRAS, ser. 3, 21 (2011), 283-300.

Wright, W.: A grammar of the Arabic language, 3rd edition, Cambridge 1896-8, repr. 1967. 